\title{
CHANGES IN PLASMA POTASSIUM AND CALCIUM LEVELS AND IN THE ELECTROCARDIOGRAM AFTER A SINGLE DOSE OF SUCCINYLCHOLINE PRECEDED BY D-TUBOCURARINE
}

\author{
William Evers, Gabor B. Racz, and Ashley A. Levy*
}

The Continuing Debate over potassium changes and arrhythmias after the administration of succinylcholine raises the question of the overall safety of this drug, and what can be done to minimize the dangers. Previous studies indicate that, except for patients with trauma, burns or neurological disorders, plasma potassium changes after succinylcholine, though present, are rarely large enough to produce any serious circulatory or electrocardiographic changes. ${ }^{1,2}$

Recent work suggests that changes in the potassium/calcium ratio may be one of the responsible factors. ${ }^{1,3}$ Small doses of d-tubocurarine (or other non-depolarizing relaxants) are known to prevent fasciculations ${ }^{4,5}$ and there are some data that would suggest that they will also prevent increases in plasma potassium concentrations as well as decrease the incidence of electrocardiographic changes, ${ }^{6-8}$

This study was undertaken to determine the influence of a small dose of d-tubocurarine prior to the administration of succinylcholine on the magnitude of changes in plasma potassium and calcium, the incidence of electrocardiographic changes, and the frequency of muscle fasciculations.

To permit a greater reliability of comparison, we chose a group of patients similar to those in our previous investigation. ${ }^{2}$

In addition we investigated the following factors:

A. Comparison of potassium and calcium levels in simultaneously drawn arterial and venous blood samples.

B. Serum creatinine phosphokinase (CPK) changes.

C. Appearance of myoglobinuria.

\section{Material}

The study extended to one hundred and eighteen patients undergoing operations under general anaesthesia for procedures not requiring immediate tracheal intubation nor producing visceral reflexes. ${ }^{2}$ Their ages ranged between 16 and 80 years. Ninety-two patients were between the ages of 21 and 60 . Seventy-eight were classified as ASA status I, 37 as II, and 3 as III (Tables I and II).

\section{MEthodS}

Induction with thiopentone $2 \mathrm{mg} / \mathrm{kg}$ was followed by nitrous oxide:oxygen

"William Evers, M.D., Gabor B. Racz, M.B., and Ashley Levy, Ph.D., Department of Anesthesiology, State University Hospital, State University of New York, Upstate Medical Center, Syracuse, New York, 13210, U.S.A.

Canad. Anaesth. Soc. J., vol. 23, no. 4, July 1976 
TABLE I

Age Distribution

\begin{tabular}{cccc}
\hline Age & Female & Male & Total \\
\hline $16-20$ & 4 & 1 & 5 \\
$21-40$ & 58 & 2 & 60 \\
$41-60$ & 34 & 1 & 35 \\
$61-80$ & 17 & 1 & 18 \\
\hline
\end{tabular}

TABLE II

A.S.A. Status Classification

\begin{tabular}{lccccc}
\hline \hline & & \multicolumn{4}{c}{ Reason for risk classification } \\
\cline { 3 - 6 } $\begin{array}{c}\text { A.S.A. } \\
\text { status }\end{array}$ & $\begin{array}{c}\text { Total no. } \\
\text { of patients }\end{array}$ & Obesity & C.V. Disease & Diabetes & Other \\
\hline I & 78 & - & -10 & - & -1 \\
II & 37 & 14 & 1 & 1 & 1 \\
III & 3 & - & & 11 & \\
\hline
\end{tabular}

60:40 and methoxyflurane ( 69 patients), enflurane ( 41 patients) and isoflurane ( 1 patient). Maintenance with nitrous oxide:oxygen and fentanyl following thiopentone induction was employed in seven patients. The electrocardiogram (Lead II) was monitored and recorded continuously.

Immediately after induction with thiopentone d-tubocurarine $6 \mathrm{mg}$ was injected intravenously and followed three minutes later by a bolus of succinylcholine ( 2 $\mathrm{mg} / \mathrm{kg}$ ). The higher dose of succinylcholine was dictated by the need for about five to eight minutes of relaxation as well as for investigation because several authors have claimed the increase in potassium release to be dose-related. ${ }^{9,4}$

Blood samples ( $3 \mathrm{ml}$ aliquots) for plasma potassium and calcium determinations were taken prior to induction, after thiopentone, after d-tubocurarine and then after succinylcholine, according to the following schedule: every 15 seconds for two minutes, every minute for ten minutes, and then at 15 minutes, giving a total of 20 samples per patient. In 15 patients simultaneous arterial and venous blood samples were obtained to compare arterial and venous potassium and calcium levels. Other analyses performed were serum CPK levels prior to induction and six hours later ( 12 patients), and urinary myoglobin ( 35 patients). In six patients it was necessary to administer a second dose of succinylcholine 15 to 20 minutes after the first; in all of these patients five additional blood samples were drawn at one-minute intervals.

\section{Results}

Plasma potassium and calcium changes were small. There was a rapid fall in potassium levels after induction and before succinylcholine was injected. The administration of succinylcholine was followed by a gradual rise in plasma potassium, a pattern seen in both venous and arterial blood. As can be seen from Figure 1 , the mean potassium values fell below the pre-induction levels. Only 11 patients showed potassium levels higher than at induction (Figure 3 ). 


\section{Mean Potassium Levels}
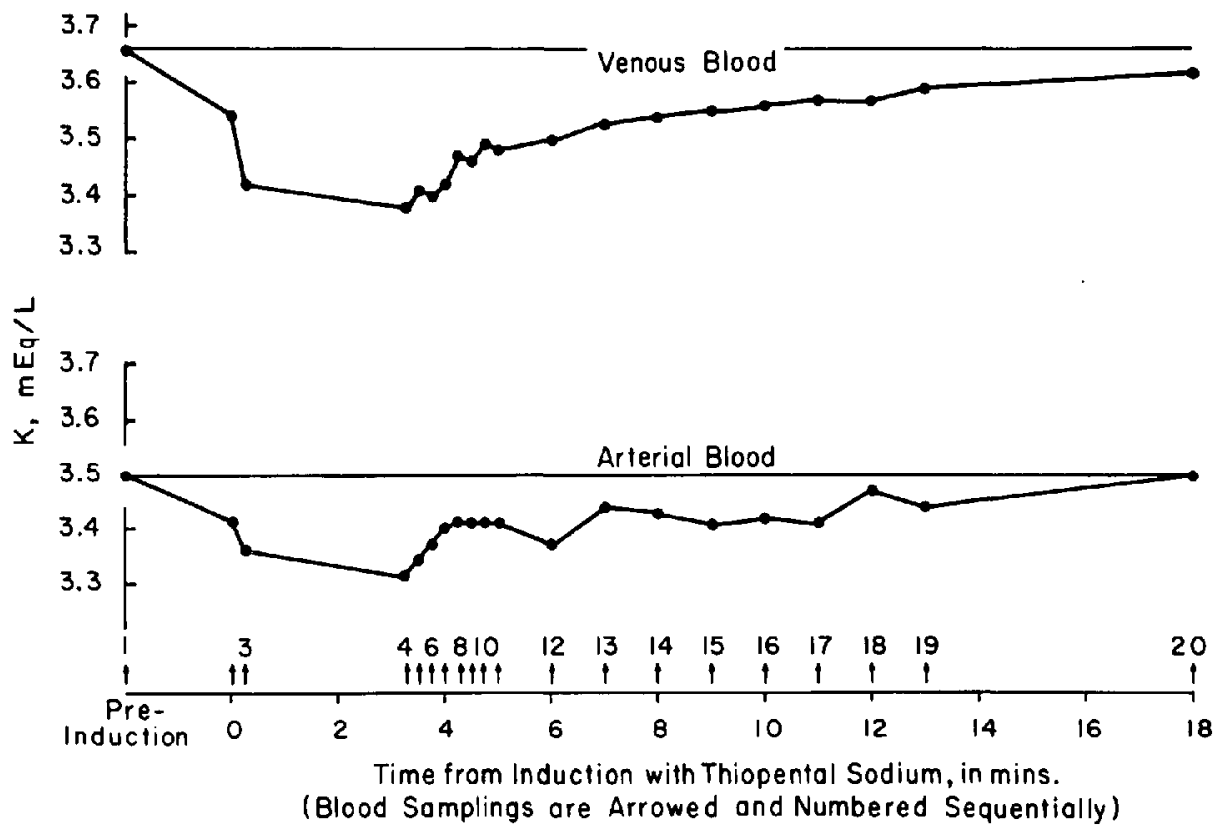

Figure 1.

Mean changes in calcium values are shown in Figure 2. A striking and unexplained drop in calcium levels in the five-minute samples (both arterial and venous) was followed by a rise one minute later. This rapid fall in mean calcium levels occurred at a time when the post-induction decline in potassium levels was ending and the gradual increase had begun. The rapid change in the $\mathrm{K}+/ \mathrm{Ca}++$ ratio during this short period of decreasing calcium and increasing potassium levels was not accompanied by an increase in the incidence of arrhythmias.

It is apparent from these data that the range over which mean potassium and calcium levels vary is so small that it does not have noticeable clinical effects. The same holds for the ranges in individual patients (Figure 3 ).

An analysis of variance was initially undertaken on the samples. This showed by means of the $\mathrm{F}$ test that the 20 blood samples taken from each patient were significantly different from each other, or, in other words, that the pattern of differences between analysis in each set of 20 would be found by chance alone less than once in a thousand for the venous samples $(p<0.001)$, and less than once in a hundred for the arterial samples $(p<0.01)$. One can conclude that the variations in potassium and in calcium levels in each patient are real variations.

A more refined statistical examination was then performed for each patient as follows: The pre-induction data served as a baseline. The area enclosed between this baseline and the tracing of the subsequent 19 points was calculated: Its overall position above or below the baseline, taken as positive or negative, represented respectively the tendency for the electrolyte concentrations to increase or to decrease. (Figure 4.) 
Mean Calcium Levels

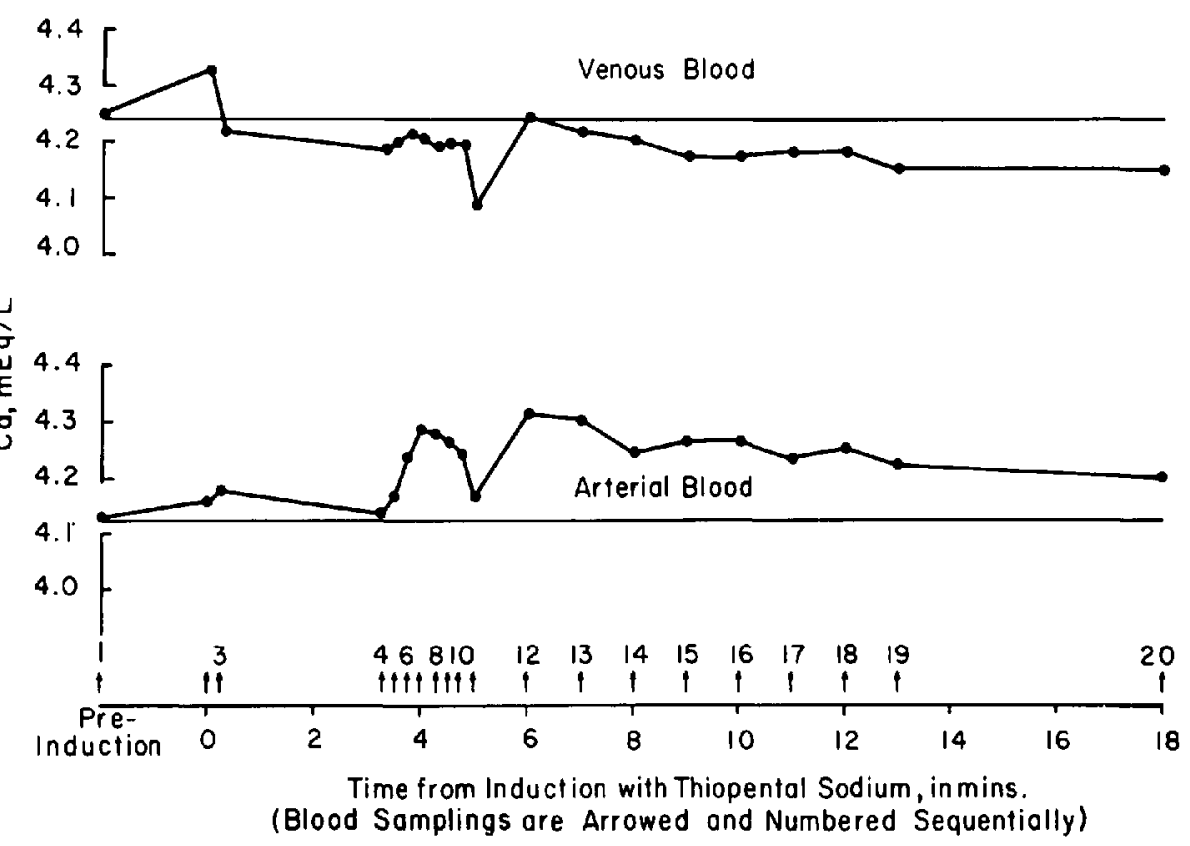

FIGURE 2.

For both potassium and calcium in venous blood the areas measured in this way were predominantly negative. The mean area measured for potassium was about 50 per cent larger than that for calcium, showing a greater degree of depression of potassium than of calcium levels. The probability of such a joint lowering of two electrolytes was calculated. The $p$ value was found to be less than 0.005 .

A multivariate analysis of variance was carried out. This has the effect of picking out significant combinations of parameters. The parameters examined in this way were age of patient, ASA status, succinylcholine dose by lean body weight, the metabolic status of the patient (probably normal or possibly abnormal), and fasciculations as noted on the operating room record (Table III).

It appears that ASA and metabolic status have no significant influence on the results. The influence of the inhalation anaesthetic had previously been found to be not significant either. On the other hand:

1. Age alone is significant at the 95 per cent confidence level; patients under 30 years of age differ from the remainder in the direction and magnitude of changes in their potassium and calcium levels (Table III).

2. The combination of age, fasciculations and succinylcholine dose (LBM) is significant. Mean changes from base levels (Table III) have no more than a 5 per cent probability of representing random scatter and a 95 per cent probability of representing real differences between their respective subgroups.

3. Changes in mean calcium from base levels are opposite in direction to changes in mean potassium. This can be stated with a $\mathrm{p}<0.005$, and is statistically highly significant. 
EVERS, et al.: PRETREATMENT WITH D'TC PRIOR TO SUCCINYLCHOLINE, ETC. 387 Maximum Ranges of $\mathrm{K}$ and $\mathrm{Ca}$ Levels, for Individual Patients

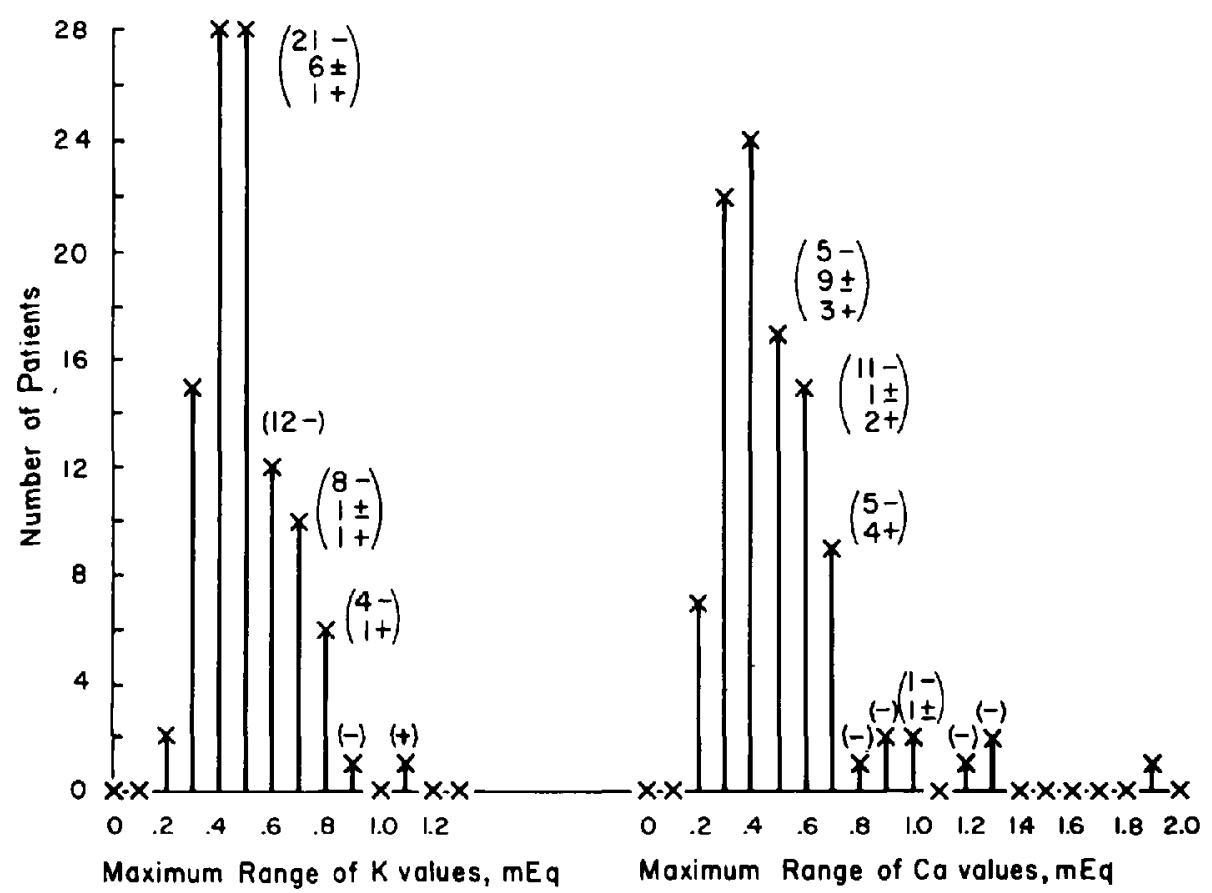

Figure 3.

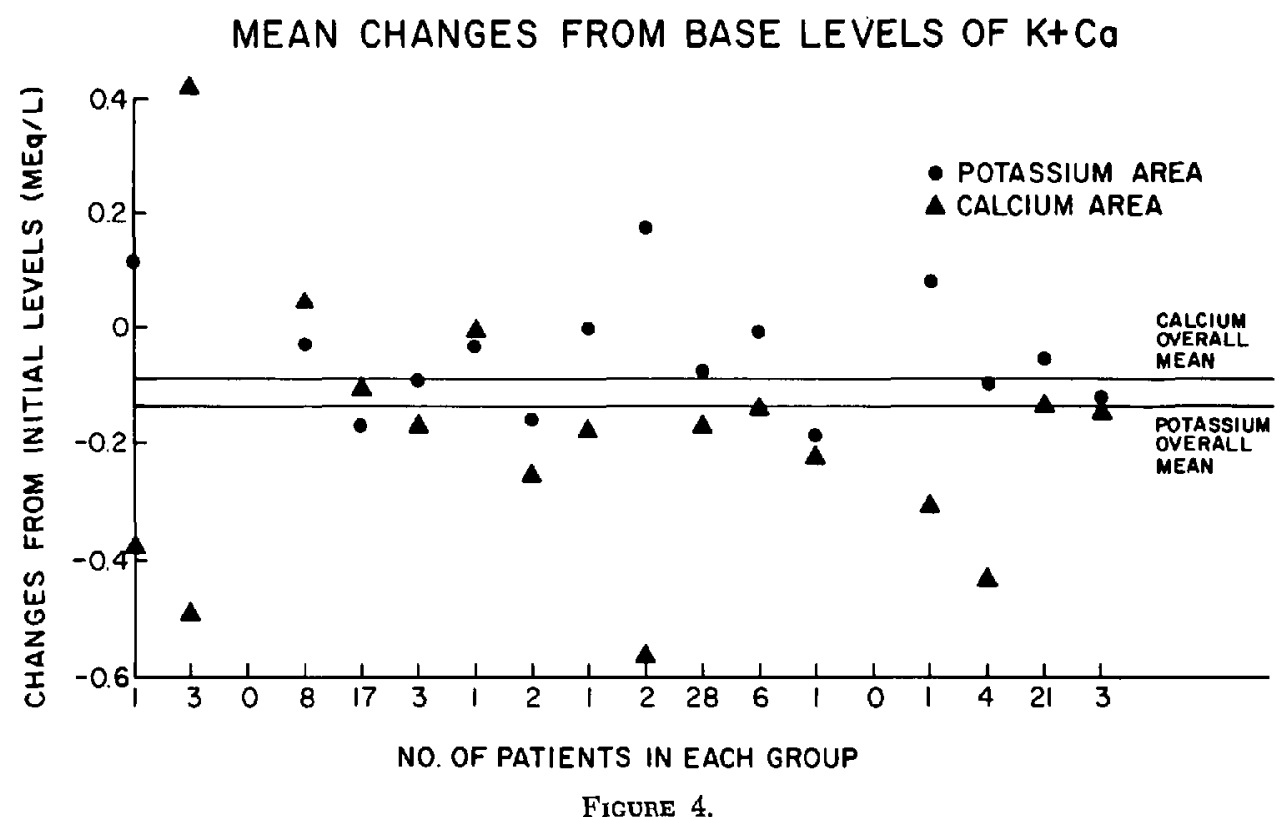

Figure 4. 
TABLE III

Potassium and Calcium Changes

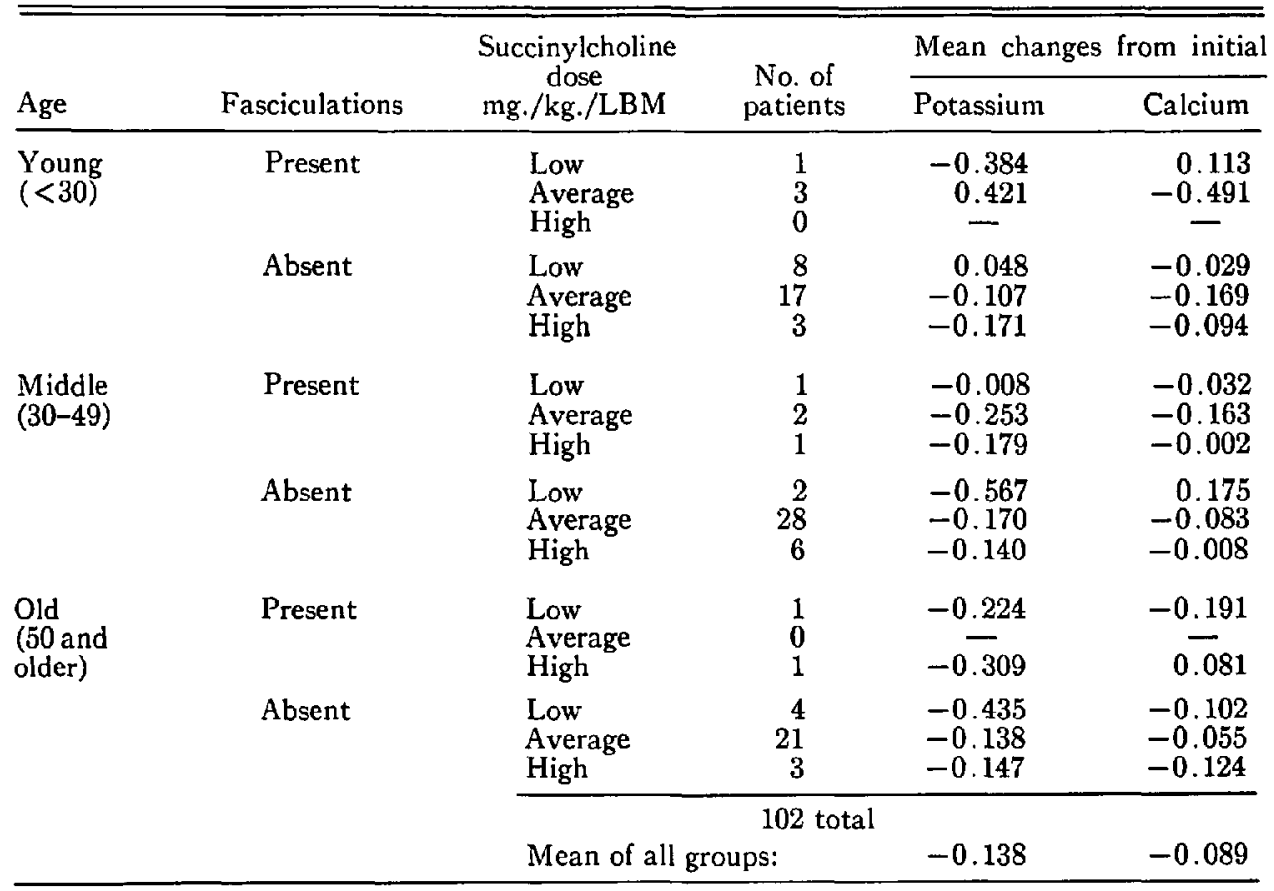

TABLE IV

Ecg Changes

\begin{tabular}{lc}
\hline \hline & $\begin{array}{c}\text { No. of } \\
\text { patients }\end{array}$ \\
\hline Sinus bradycardia & 17 \\
Sinus suppression & 8 \\
Nodal (junctional) rhythm & 3 \\
Sinus tachycardia & 4 \\
Non-specific P-wave changes & 1 \\
$\quad$ Total & 33 \\
\hline
\end{tabular}

ECG Changes: Thirty-three patients showed electrocardiographic changes: sinus bradycardia (17 patients), sinus suppression with nodal predominance (eight patients), frank nodal (junctional) rhythm (three patients), sinus tachycardia (four patients) and non-specific P-wave changes (one patient) (Table IV).

There was no correlation between changes in potassium levels and ECG abnormalities. Though potentially dangerous, all ECG changes were transient and without any concomitant alterations in haemodynamics.

Only one patient showed a six-hour increase in creatinine phosphokinase: from 10 to $25 \mathrm{I} . \mathrm{U}$. (normal range is 0 to $34 \mathrm{I}$.U.). Urinary myoglobin was negative in all 35 patients tested. Fasciculations (mild and periorbital only) were observed in 11 patients. The changes of potassium levels in the six patients receiving a second 
EVERs, et al.: PRETREATMENT WITH D'TC PRIOR TO SUCCINYLCHOLINE, ETC. 389

dose of succinylcholine were insignificant (between -0.1 and $+0.2 \mathrm{mEqL}$ ). No ECG abnormalities were found after the second dose.

\section{Discussion}

The rapidity and magnitude of potassium release after succinylcholine appears to be of the utmost importance. Previous studies indicated quite clearly that increases in potassium are not confined only to certain categories of patients. ${ }^{10,2,11}$ The release of potassium in patients with trauma, burns or neurological disorders is a quantitatively and qualitatively different response as compared to that in other subjects. The explanation for these differences is not yet quite clear. Some authors suggest that traumatized, denervated, or otherwise abnormal muscles release potassium not only at the endplates of the myoneural junctions, but from the entire muscle mass. Such an increased sensitivity ("super-sensitivity") of the chronically denervated muscle has been described for acetylcholine. ${ }^{12-15}$ The increased sensitivity results in an increased membrane permeability for potassium, sodium and other ions. Such effect could also hold true for the chemically similar succinylcholine; thus, the entire denervated muscle would become a huge depolarizing area with concomitant outpouring of potassium, calcium and sodium. ${ }^{12,16-18}$ This would indicate a change in cellular permeability of potassium, permitting $\mathrm{K}_{\mathrm{I}}$ to leak out, but delaying or preventing $\mathrm{K}_{0}$ from returning into the cell, usually a very rapid process in normal muscular contractions. ${ }^{10}$

In that case, altered cellular permeability could also contribute to the massive potassium release after succinylcholine in burned patients, especially during the toxic and hypermetabolic phase. Stabilization of the cellular membrane, on the other hand, would tend to minimize changes in the ionic flux. D-tubocurarine, pancuronium and gallamine may be such stabilizers. ${ }^{17,19}$

Besides this biochemical factor, one must also consider the mechanical aspects of sudden massive muscular contractions; strenuous muscular exercise, whether short-lasting (e.g. wrestling matches) or prolonged (forced marches, football) does produce disruption of myofibril integrity, resulting in release of potassium and free myoglobin. ${ }^{20-22}$ Were this a major contributing factor, prevention of postsuccinylcholine fasciculations should result in a decrease, if not elimination, of the potassium changes as well as essentially unchanged CPK values. This idea was first suggested by Klupp ${ }^{9}$ and Mayerhofer ${ }^{23}$ and later by several others. ${ }^{10,24,25,6} \mathrm{On}$ the other hand, some authors questioned the predictability of preventing potassium increase by the preliminary use of pachycurares. ${ }^{17}$ Others disclaimed any potassium-lowering effect. ${ }^{26-28}$

This rather vast difference of opinions and results may be due to different sampling techniques and clinical material. ${ }^{29}$ Our present data come from an almost identical patient population, as in our first study, ${ }^{2}$ with no changes in technique or personnel, and therefore comparison with the previous results - where d-tubocurarine was not used - appear more reliable.

Cardiac Arrhythmias Associated with Succinylcholine: An interesting light is shed on this subject by comparing our data with those of other authors. Although Mathias $^{8,30}$ claims that the "cardiac action of succinylcholine is abolished by 
d-tubocurarine, toxiferin, and other non-depolarizing agents," this was not the case in our study. If one assumes that both the rise in potassium and the incidence of arrhythmias would be increased by possible hypoxia due to an increase in oxygen consumption, ${ }^{31,32}$ then the incidence of arrhythmias should be lowered where the above factors have been decreased, if not eliminated. This assumption is not supported by available data. ${ }^{31}$ Stoner $^{33}$ believes that ventricular arrhythmias could be due to succinylcholine since, like acetylcholine, it can stimulate the discharge of catecholamines.

The majority of recent data, however, point to the preponderance of cholinergic effects: bradycardia, sinus arrhythmias, sinus suppression and junctional (nodal) thythm. The bradycardia and bradyarrhythmias of the so-called second-dose effect can be treated successfully and often prevented by atropine. Mathias and associates $^{8}$ suggested that non-depolarizing muscle relaxants d-tubocurarine, pancuronium and alcuronium will produce the same effect. This hypothesis seems to be corroborated by studies on the influence of leptocurares and pachycurares on the methanesulfonylation of acetylcholinesterase. ${ }^{34}$

In addition, one must consider that succinylcholine, just as acetylcholine, may have a direct effect on the myocardium and the conductive system of the heart. ${ }^{35-38}$ This, combined with peripheral vasodilation, ${ }^{39,40}$ may produce cardiovascular collapse in a hypovolaemic, acidotic, or poor-risk patient.

Our findings ( Table IV) indicate that, in spite of insignificant changes in potassium and calcium levels, the incidence of arrhythmias did not decrease and their overall acetylcholinmimetic character did not change. The possibility of arrhythmias being caused by an increase in the potassium/calcium ratio was advanced by List ${ }^{1,3}$ who found a positive correlation in 32 patients (most of them digitalized) between increases in potassium/calcium ratio and the incidence of ventricular arrhythmias. No changes in calcium levels after succinylcholine have been reported by several authors. ${ }^{1,3,16,41}$ Our data indicate somewhat lowered calcium levels but, although changes are statistically significant, their clinical importance is doubtful, particularly insofar as ventricular arrhythmias are prevalent in digitalized and hypercalcaemic, rather than in hypocalcaemic patients. ${ }^{42}$

Furthermore, during the short period, when plasma calcium levels were falling and potassium levels rising (Figures 1 and 2), no increase in the incidence of arrhythmias was observed.

CPK Changes and Myoglobinuria: Increase in CPK values is a very sensitive test for muscle damage. Changes were described after intramuscular injections, ${ }^{43,44}$ exercise, ${ }^{45}$ and succinylcholine. ${ }^{27,46-49}$ Myoglobinuria, not unusual after strenuous exercise, has been described after succinylcholine. ${ }^{27,46,47}$ Leikkonen $^{27}$ found increased CPK even in patients receiving succinylcholine after a $0.1 \mathrm{mg} / \mathrm{kg}$ dose of d-tubocurarine. He believed that muscular hypoxia and hypoglycaemia increase cellular permeability, especially after rapid fasciculation. On the other hand, Tammisto $^{28}$ claims that d-tubocurarine will block increases in CPK, although apparently not increases in potassium.

Our data indicate that, when fasciculations are eliminated or markedly decreased by precurarization, changes in CPK levels are negligible and myoglobinuria, another indication of myofibrillar damage, is absent. 


\section{SUMMARY}

One hundred and eighteen patients undergoing surgical procedures not requiring immediate tracheal intubation, nor producing visceral reflexes, were pretreated with d-tubocurarine $6 \mathrm{mg}$, three minutes before the administration of a bolus of succinylcholine $(2 \mathrm{mg} / \mathrm{kg})$.

Electrocardiographic changes, venous and arterial plasma potassium and calcium levels, CPK changes ( 12 patients) and appearance of myoglobinuria ( 35 patients) were followed.

Pretreatment with a small dose of d-tubocurarine did not change the overall incidence and pattern of arrhythmias; it did, however, prevent increases in plasma potassium in 90.4 per cent of the patients, mean plasma potassium values remaining below pre-induction levels. The CPK level changed in only one of 12 patients (from 10 to 21 I.U., the normal range being 0 to 34 I.U.). No myoglobinuria was detected in any of the patients tested. A rapid but short-lasting change in the $\mathrm{K}^{+} / \mathrm{Ca}^{++}$ratio did not seem to influence the occurrence of arrhythmias.

Pretreatment with a small dose of d-tubocurarine is effective in preventing or decreasing fasciculations, plasma potassium and CPK changes and myoglobinuria described after the intravenous administration of succinylcholine.

The already useful role of succinylcholine in our armamentarium can be made safer by pretreatment with a small dose of d-tubocurarine.

\section{Conclusions}

In the average patient, a small dose of d-tubocurarine (and probably other pachycurares) will effectively prevent significant changes in plasma potassium after a single dose of succinylcholine. This is most likely due to the membranestabilizing effect ascribed to d-tubocurarine and other pachycurares.

Whether this action of d-tubocurarine can also protect against the dangerous increases in potassium levels in special categories of patients (burns, trauma, neurological diseases) is, as yet, not adequately documented. Until such doubts are cleared, it appears wise to avoid using succinylcholine in these instances.

Pretreatment with d-tubocurarine does not seem to affect the incidence of ECG changes after succinylcholine. Here as in our previous study, all of the ECG abnormalities were transient and had no effect on haemodynamics.

Taking all factors into consideration, we should not deprive ourselves of the useful role of succinylcholine in anaesthesia, especially when pretreatment with d-tubocurarine and probably with other pachycurares seems to offer so many advantages and only minor disadvantages.

\section{RÉSUMÉ}

Cent dix-huit malades subissants chirurgie sans necessité d'intubation, ni produissante de réflexes visceraux ont reçu $6 \mathrm{mg}$ de la d-tubocurarine trois minutes avant l'administration d'une dose de la succinylcholine à $2 \mathrm{mg} / \mathrm{kg}$.

Nous avons suivi l'ECG, les taux artériels et veineux du potassium et calcium plasmatique, CPK ainsi que l'apparition d'une myoglobinurie. 
L'administration préalable d'une petite dose de la d-tubocurarine ne change pas ni l'incidence ni le caractère d'arythmies cardiaques. Elles sont à peu prés les mêmes que nous avons signalé dans notre travail précedent.

La hausse du taux plasmatique du potassium était prevenue chez 90.4 pour cent des nos malades. En effet le taux moyen du potassium était au dessous de la valeur préinduction.

Le taux de la CPK n'a changé que chez une malade, d'ailleurs d'une façon insignifiante (de 10 a 21 u.i.).

Les épreuves pour myoglobinurie étaient negatives chez tous les 35 malades etudiés.

La prémedication avec une petite dose de la d-tubocurarine nous semble prudent and souhaitable, puisqu'elle permet d'éliminer certains dangers associés avec l'usage de la succinylcholine, un agent très utile dans notre specialité.

\section{REFERENCES}

1. List, W.F. Succinylcholine-induced arrhythmias. Anesth. \& Analg. 50: 361 (1971).

2. Evers, W., RACz, G.B., \& Dobkin, A.B. A study of plasma potassium and electrocardiographic changes after a single dose of succinylcholine. Can. Anaesth. Soc. J. 16: 273 (1969).

3. List, W.F. Calcium und kaliumveranderungen im serum wahrend der narkoseeinleitung. Anaesthesist 17: 221 (1968).

4. Cullen, D.J. The effect of pretreatment with non-depolarizing muscle relaxants on the neuromuscular blocking action of succinylcholine. Anesthesiology 35: 572 (1971).

5. TAKki, S., Kauste, A., \& KJELlberc, M. Prevention of suxamethonium-induced fasciculations by prior dose of d-tubocurarine. Acta Anesth. Scand. 16: 230 (1972).

6. Weinthaub, H.D., Heisterkamp, D.V., \& Cooperman, L.H. Changes in plasma potassium concentration after depolarizing blockers in anesthetised man. Brit. J. Anaesth. 41: 1048 (1969).

7. Kanhunen, U., Heinonen, J., \& Tammisto, T. The effect of tubocurarine and alcuronium on suxamethonium-induced changes in cardiac rate and rhythm. Acta Anaesth. Scand. 16: 3 (1972).

8. Mathias, J.A., Evans-Prosser, C.D.G., \& Churchill-Davidson, H.C. The role of the non-depolarizing drugs in the prevention of suxamethonium bradycardia. Brit. J. Anaesth. 42: 609 (1970).

9. Klupp, H., Kraupf, O., Honetz, N., Kobinger, W., \& Loudon, M. Über die freisetzung von kalium aus der muskulatur unter einwirkung einiger muskelrelaxantien. Arch. Int. Pharmacodyn 98: 340 (1954).

10. Birch, A.A., Mitchell, G.D., Playfond, G.A., \& Lang, C.A. Changes in serum potassium response to succinylcholine following trauma. J.A.M.A. 210: 490 (1969).

11. List, W.F. Serum potassium changes during anesthesia - a possible cause of cardiac arrhythmias? Proc. IV World Congr. Anaesth., London (1968). Excerpta Medica Found. p. 1148, Amsterdam (1970).

12. TheslefF, S. Nervous control of chemosensitivity in muscle. Ann. N.Y. Acad. Sci. 94: $535(1961)$.

13. Stone, W.A., Beach, T.P., \& Hamelbehg, W. Succinylcholine-Danger in the spinal-cordinjured patient. Anesthesiology 32: 168 (1970).

14. Stone, W.A., Beach, T.P., \& HamelberG, W. Succinylcholine-induced hyperkalemia in dogs with transected sciatic nerves or spinal cords. Anesthesiology 32: 515 (1970).

15. Axelsson, J. \& TheslefF, S. A study of supersensitivity in denervated mammalian skeletal muscle. J. Physiol. 147: 178 (1959).

16. Cooperman, L.H., Strobel, G.E., JR., \& Kennell, E.M. Massive hyperkalemia after administration of succinylcholine. Anesthesiology 32: 161 (1970).

17. Coopenman, L.H. Succinylcholine-induced hyperkalemia in neuromuscular disease. J.A.M.A. 213: 1867 (1970). 
18. Tobey, R.E., Jacobsen, P.M., Kahle, C.T., Clubb, R.J., \& Dean, M.A. The serum potassium response to muscle relaxants in neural injury. Anesthesiology $37: 332$ (1972).

19. Gronert, G.A., Lambert, E.H., \& Theye, R.A. The response of denervated skeletal muscle to succinylcholine. Anesthesiology 39: 13 (1973).

20. Hamilton, R.W., Gardner, L.B., Penn, A.S., \& Goldberg, M. Acute tubular necrosis caused by exercise-induced myoglobinuria. Ann. Int. Med. $77: 77$ (1972).

21. Greenberg, J. \& ArnesoA, L. Exertional rhabdomyolysis with myoglobinuria in a large group of military trainees. Neurology 17: 216 (1967).

22. Eliot, R.S., Shafer, R.B., \& Grbas, M.A. Demonstration of myoglobinemia in football players. Arch. Phys. Med. 48: 229 ( 1967 ).

23. MAYERHOFER, $O$. Die wirksamkeit von d-tubocurarin zur verhütung der muskelschmerzen nach succinylcholin. Anaesthesist 8: 313 (1959).

24. Roth, F. \& SAIDI, M. Dangerous increases in serum potassium following succinylcholine. Anaesthesist 20:35-38 (1971).

25. Stevenson, D.E. Changes in the blood electrolytes of anaesthetised dogs caused by suxamethonium. Brit. J. Anaesth. 32: 364 (1960)

26. Gronert, G.A. Potassium response to succinylcholine. J.A.M.A. 211: 300 (1970).

27. Leikkonen, P. \& Airaksinen, M. The inhibitory effect of d-tubocurarine on the increase of serum creatine-kinase activity produced by intermittent suxamethonium administration during halothane anaesthesia. Acta Anaesth. Scand. 11: 330 (1967).

28. Tammisto, T., Leikkonen, P., \& Airaksinen, M. The inhibitory effect of d-tubocurarine on the increase of serum-creatine-kinase activity produced by intermittent suxamethonium administration during halothane anaesthesia. Acta Anaesth. Scand. 11: 333 (1967).

29. Wollman, H. The elephant's ears can be misleading. Anesthesiology 35: 566 (1971).

30. Mathias, J.A. \& Evans-Prosser, C. An investigation into the site of action of suxamethonium on cardiac rhythm. Proc. IV World Congr. of Anaesth., London (1968), Excerpta Med. Found., p. 1153, Amsterdam (1970).

31. Muldoon, S.M. \& Theye, R.A. The effects of succinylcholine and d-tubocurarine on oxygen consumption. Anesthesiology 31: 437 (1969).

32. Theye, R.A. The effect of succinylcholine on canine gastrocnemius-muscle oxygen consumption. Anesthesiology 32: 537 (1970).

33. Stoner, T.R., JR. \& Urbach, K.F. Cardiac arrhythmias associated with succinylcholine in a patient with pheochromocytoma. Anesthesiology 29: 1228 (1968).

34. Belleau, B., DiTullio, V., \& Tsai, Y.H. Kinetic effects of leptocurares and pachycurares on the methanesulfonylation of acetylchol:esterase. A correlation with pharmacodynamic properties. Mol. Pharmacol. 6: 41 (1970).

35. Blumenthat, M.R., Wang, H., MarkeE, S., \& Wang, S.C. Effects of acetylcholine on the heart. Am. J. Physiol. 214: 1280 (1968).

36. Gologorsky, V.A. \& UManov, J.M. The influence of lystenon on cardiac function. Vestn. Khir. 7: 102 (1965).

37. Golocorsky, V.A. \& UManov, J.M. The mechanism of succinylcholine effect on heart rate and rhythm. Proc. IV World Congr. of Anaesth., London (1968), p. 1165, Excerpta Medica Found., Amsterdam (1970).

38. Molino, N., Xiume, G.B., \& Calabrese, S. L'azione della succinilcolina sul batmotropismo cardiaco dei mammiferi. Minerva Cardioangiologica 8: 74 (1960).

39. ANDREEN, M. \& W AHLIN, A. The effect of muscle relaxants on peripheral blood flow. Intem. Anesth. Clinics 7: 303 (1969).

40. Graf, K., Strom, G. \& Wahlin, A. Circulatory effects of succinylcholine in man. Acta Anaesth. Scand., Supplementum XIV (1963).

41. TobeY, R.E. Paraplegia, succinylcholine and cardiac arrest. Anesthesiology 32: 359 (1970).

42. Smith, R.B. \& Petruscak, J. Succinylcholine, digitalis and hypercalcemia. A case report. Anesth. \& Analg. 51: 202 ( 1972).

43. Meltzer, H.Y., Mrozak, S., \& Boyer, M. Effect of intramuscular injections on serum creatinine phosphokinase activity. Amer. J. Med. Sci. 259: 42 (1970).

44. Cohen, L. CPK test-effect of intramuscular injection in myocardial infarction. J.A.M.A. 219: 625 (1972).

45. Meltzer, H. \& Moline, R. Plasma enzymatic activity after exercise. Arch. Gen. Psychiat. 22: $390(1970)$.

46. Pallechi, A.E., Dall'onso, F., \& Fossa, S. Muscle pain secondary to administration of succinylcholine and various anesthetics. Evaluation based on the increase of serum aldolase and CPK activity. Acta Anaesth. (It.) 19: 1113 (1968). 
47. Perkoff, G.T. Effect of succinylcholine on creatine phospho-kinase (CPK) in anaesthetized dogs. J. Lab. Clin. Med. 74: 153 (1969).

48. Tammisto, T. \& Airaksinen, M. Effect of some anaesthetics on the increase of serum creatine-kinase activity in cats by depolarizing agents. Ann. Med. Exp. Fenn. 44: 404 (1966).

49. Tammisto, T., Brander, M., \& Airaksinen, M. Hypoxia and suxamethonium-induced muscle injury. Brit. J. Anaesth. 41: 276 (1969). 